Egypt. Acad. J. Biolog. Sci., 11(1): 1- 14 (2019)

Egyptian Academic Journal of Biological Sciences

D. Histology \& Histochemistry

$2090-0775$

www.eajbs.eg.net

\title{
Ultrastructure of Ovarian Follicular Epithelium During Oogenesis in Lucilia silvarium (Diptera: Calliphoridae)
}

\author{
Khater, K.S \\ Department of Zoology, Faculty of Science, Zagazig University, Zagazig-44519, \\ Sharkia, Egypt. \\ E.Mail.: k_s_kamel@hotmail.com
}

ARTICLE INFO

Article History

Received: $5 / 1 / 2019$

Accepted: 22/2//2019

Keywords:

Ultrastructure, oocyte, nurse cells, vitellogenesis, eggshell, Lucilia silvarium.

\section{INTRODUCTION}

Lucilia is one of the most important blowflies due to their occurrence on animal and human dead bodies (Smith, 1986; Dodge, 1952; Brothers, 1970; Prado e Castro et al., 2011). This genus is belonging to family Calliphoridae. These flies have worldwide distribution and they are agents of some serious medical problems and losses to the animal industry (Ghandour, 1988; David et al., 2008). The common name toad fly is usually used because this fly has a strong preference for living toads (Bolek and Janovy, 2004) and dead frogs (Groth and Reissmüller, 1973). Larvae of this fly invade animal tissue causing myiasis (Eaton et al., 2008).

Many studies on the female reproductive system of other insect species, especially blowflies were carried out, Spradbery and Sands (1976) on Chrysomya bezziana, Bansal and Murad (1987) on C. megacephala, and Anan'ina et al. (2010) on Calliphora erythrocephala). Data on the morphology and ultrastructure of adults of $L$. silvarium female reproductive system are very scarce. Adult female of $L$. silvarum has two polytrophic ovarioles, each ovariole composed of a successive number of developing follicles. It is well known that somatic follicular cells form a single epithelial layer enclosing the germ cells in previtellogenesis, but during egg 
development, these cells differentiate morphologically to a number of distinct subtypes each play role in formation of eggshell. The structure of ovary and morphological changes in follicular epithelium may be useful in taxonomic identifications and in phylogenetic relations between dipteran insects (Jaglarz et al., 2008).

The present study aims to investigate the structure of ovarian follicular epithelium at different developmental stages in this species using Light Microscopy (LM) and Transmission Electron Microscopy (TEM) which may be useful in insect control.

\section{MATERIALS AND METHODS}

\section{Insects:}

Insects of $L$. silvarium were collected as larvae from beef meat in Sharkia Governorate, Egypt in autumn of 2014 and reared in the laboratory of Zoology Department in Zagazig University. The insects reared according to the methods of ElKhateeb et al. (2003).

\section{Histological Technique:}

Ovaries isolated from the dissected female flies were put in aqueous Bouin's fixative. After fixation ovaries washed several times with $70 \%$ ethyl alcohol to remove the yellow colour of Bouin's solution then dehydrated in ascending series of ethanol. The specimens were then cleared in xylene, embedded in paraffin blocks and cut sections $(4 \mu \mathrm{m}$ thick) using microtome and stained with haematoxylin and eosin.

\section{Transmission Electron Microscopy Technique:}

In TEM investigation, the ovaries were dissected from 1, 6 and 10- day old females. Fixation in $2.5 \%$ glutaraldehyde in phosphate buffer for $24 \mathrm{~h}$ takes place and then put in osmium tetroxide (1\%) for 2-3 $\mathrm{h}$. Whole ovaries were dehydrated with ascending series of alcohol and dried in acetone. The specimens were embedded in resin and incubating at $70^{\circ} \mathrm{C}$ for $24 \mathrm{~h}$. the semi-thin sections stained with methylene blue for light microscopy examination. The ultrathin sections were cut and stained by uranyl acetate and lead citrate and photographed in a JEOL 1200 EXIL Transmission Electron Microscope at the Electron Microscope Unit, Faculty of Pharmacy, Al Azhar University.

\section{RESULTS}

The female reproductive system of the adult of $L$. silvarium has the same morphological pattern of other members of family Calliphoridae. In our knowledge, this is the first time to describe the female reproductive system of this medically important fly. The female reproductive system consists of pair ovaries, each ovary consists of polytrophic ovarioles (Fig. $1 \mathrm{a} \& \mathrm{~b})$. Each ovary leads to lateral oviduct the two oviducts join to form a common oviduct. Two accessory glands enter the vagina and the spermathecal glands are represented by three sclerotized spermathecae. Pair of these glands are connected and the third is separate (Fig.1a\& b). The ovaries reach the maximum size of development by ten days of age (Fig.1b). Each ovary supplied with many tracheoles which have silver color in the fresh dissected female reproductive ovary (Fig.1a). Each ovariole has a number of ovarian follicles, these follicles arranged in the order that the younger follicles lie closer to the germinal cells, while the mature follicles lie at the posterior region. The younger follicle consists of the germ cell enveloped by a single layer of epithelium (Figs. 1 e, f, 2a\& b). The germ cells differentiate into the nurse cells and the oocyte. Both the nurse cells and the developing oocyte are containing a somewhat rounded nucleus (Figs. 2b, f\& 3a). The follicular epithelium diversified itself during oogenesis and accommodate 
themselves to fit the increasing volume and growing of the developing oocyte. The developmental stages of ovarian maturation were investigated in the present study. Stages of ovarian development can be summarized in the following stages.

Stage I ( 0 -2 days), is the initial stage in oogenesis. Each ovariole of the newly emerged female has piriform germ cells. The follicles are not differentiated from the germinal cells (Fig. 1c).

Stage II (day 3) differentiates into early second stage in which the formation of nurse cell compartment is observed (Fig.1d) and a late second stage that shows spherical follicle separated from germarium by constriction. The nurse cells present occupies most of the follicle and enclosed by thick cubical epithelium. The follicular epithelium differentiates to polar cells at opposite poles of the developing oocyte (Fig.1e\&f).

The ovarian follicle in stage III (4 days) enlarges and formation of the first egg chamber has appeared posteriorly. The ovarian follicles occupied mostly by the nurse chamber (Fig. 2b\& c). The oocyte and the nurse cells are similar in size. The oocyte appears in the basal portion of the follicle and faintly stained in comparison with the nurse cells. The nurse cell nucleus is larger than the oocyte nucleus (Fig. 2b). The follicular epithelium form centripetal cells in between nurse cell chamber and the egg chamber (Fig. 2c).

The first egg chamber in stage IV (5, 6 days) is completely separated from the second egg chamber by an interfollicular stalk. The nurse cells are present at the anterior pole of the first egg chamber. The chromatin varies in appearance in different nurse cells; some appear more condensed than others. The follicle increases and yolk deposition around the oocyte nucleus become obvious. The follicular cells surrounding the oocyte become columnar and those surrounding the nurse cells become squamous (Fig. $2 \mathrm{~d} \& \mathrm{e})$.

Stage V (7, 8 days) is characterised by increasing yolk deposition around the oocyte nucleus. The yolk appears in two forms, large and small granules. The follicle became larger and elongated. The oocyte has attained one third to half of the entire follicle (Fig. 2d).

The oocyte continues to grow in stage VI (9days) and fill the two third of the follicle. The nurse cells fill the rest third anterior to the oocyte (Fig. 3a).

The diagnostic feature of stage VII (10 days) is the increase in length, decrease in width of the follicle and it became narrower. The nurse cells greatly reduced to fill only the anterior pole of the ovarian follicle. The follicular cells enclosing the oocyte are still present and have very thin form, which had participated in chorion formation (Fig. 3b).

The final stage in oogenesis is stage VIII (11-12 days) where the follicle reaches its final size and shape and the oocyte fills the entire follicle, moreover the nurse cells have been completely disappeared. The oocyte nucleus was not detected, and the development of the nucleus after this stage was not traced (Fig. 3c). Each ovariole has ova to be deposit after formation of eggshell.

The egg completes its development after three phases, pre-vitellogenesis, vitellogenesis and post- vitellogenesis processes. The pre-vitellogenesis include stage II and stage III. The vitellogenesis extends from stage IV to stage VII and post- vitellogenesis achieved at the end of stage VIII. These three phases could be observed and identified in the ovarioles of $L$. silvarium females. In the previtellogenic phase (stages II\& III), the ovariole sections are spherical and have cubical follicular epithelial cell 
layer surrounding the oocyte and the nurse cells. The follicular epithelial cells contain large nuclei with prominent chromatin. The cytoplasm revealed different sizes of mitochondria, onion shape or lamellar shape rough endoplasmic reticulum (lamellar body) and lipid droplets (Fig. 3f). Presence of Golgi apparatus near the nucleus reveals the secretory function of follicular epithelium (Fig. $3 \mathrm{~d})$. This apparatus may be responsible for the formation of the special vesicles which have been observed in TEM photograph. Presence of gap junction between the two follicular cells was clearly observed (Fig. 3e).

The vitellogenic phase includes the stages IV, V, VI\& VII. The ovariole in the fourth stage has follicular epithelium elongated to become columnar type surrounding the developing oocyte (Fig. 4a) and squamous enclosing the nurse cells (Fig. 5a\& b). The columnar cell has large nuclei contain periphery located condensed chromatin. The numerous lipid droplets are present and special vesicles have rosette shape also noticed (Fig. $4 a \&$ b). The oocyte contains many rounded shaped mitochondria are located in the ooplasm, numerous lipid droplet and electron dense yolk granules have different sizes (Figs. $4 \mathrm{c}$ $\& 5 \mathrm{c})$. A clear tight junction observed between two follicular cells (Fig. 4b) and between stretched follicular epithelium enclosing the nurse cells and the oocyte (Fig. 5a).

In post vitellogenic phase include the stage VIII, at the end of this stage the follicular epithelial cells become very thin and hardly observed and the eggshell formation is completed (Fig. 3c). The eggshell composed of the outermost extinct follicular cell layer, chorion, a wax layer, vitelline envelops and the trabecular layer arranged, respectively. The chorion usually subdivided into three sublayers of exochorion, endochorion, and innermost endochorion. Meanwhile, the vitelline membrane does not show any subdivisions or modification (Fig. 5e).

During previtellogenesis the developing oocytes are surrounded by cubical follicular epithelium. The follicular cell diversified into polar cells at the opposite side of the developing oocyte (Fig.1e\& f).The anterior polar cells diversified to terminal cells (Fig. 2a). The posterior polar cells form the main body follicular cells (Fig. 2d\& f). During vitellogenesis, the terminal cell diversified to stretched cells and centripetal cells (Fig. 2c). Stretched cells become squamous and enclose the nurse cells (Figs. 2d, e, 5a\& b). The centripetal cells migrate to the anterior of oocyte and separate between the nurse cells and the oocyte (Fig. 2c).The main-body follicular cells elongated and become columnar and covered the lateral sides of the developing oocyte (Figs. 3d, $4 a \&$ b). As the oogenesis progress and after complete deposition of yolk, the nurse cells transfer their cytoplasm to the oocyte and the nurse cells undergo apoptosis. The nucleus becomes irregular in shape and show strong blebbing or zeiosis in nuclear envelop and the cytoplasmic organelles disappeared (Fig. 5d). During the final stage of oogenesis, the follicular cells produce the complex eggshell around the oocyte (Fig. 5e). 

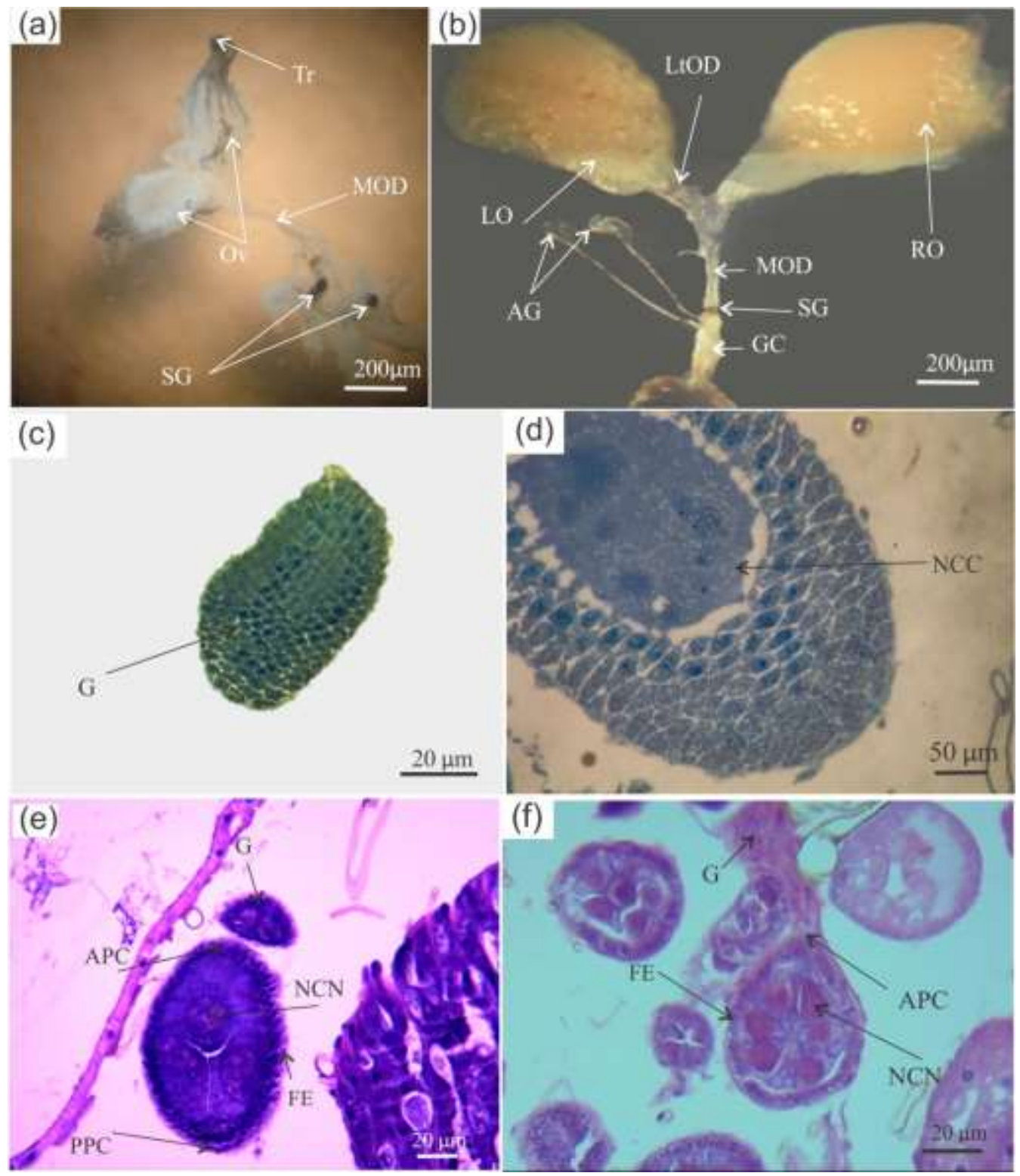

Fig.1 a-b) Stereophotograph of female reproductive system of Lucilia silvarium a) One day old female showing numerous trachea, paired ovaries, median common oviduct and three spermthecal glands; b) Seven days old female showing paired ovaries (left and right), paired lateral oviduct, median common oviduct, paired accessory glands, three spermthecal glands and genital chamber; c) Semithin section of first stage of oogenesis showing undifferentiated germinal cells; d) Semi-thin section of early second stage of oogenesis showing formation of nurse cell chamber; e-f ) Photomicrograph of cross section of second stage of oogenesis showing, e) Anterior and posterior polar cells; f) Nurse cells and anterior polar cells at the anterior pole of developing oocyte. (AG) accessory gland; (APC) anterior polar cells; (FE) follicular epithelium; (G) germarium; (GC) genital chamber; (LO) left ovary; (Lt OD) lateral oviduct; (NCC) nurse cell chamber; (MOD) median common oviduct; (NCN) nurse cell nucleus; $(\mathrm{ON})$ oocyte nucleus; $(\mathrm{OV})$ ovary; $(\mathrm{PPC})$ posterior polar cell; (RO) right ovary; $(\mathrm{SG})$ spermthecal gland; (Tr) trachea. 

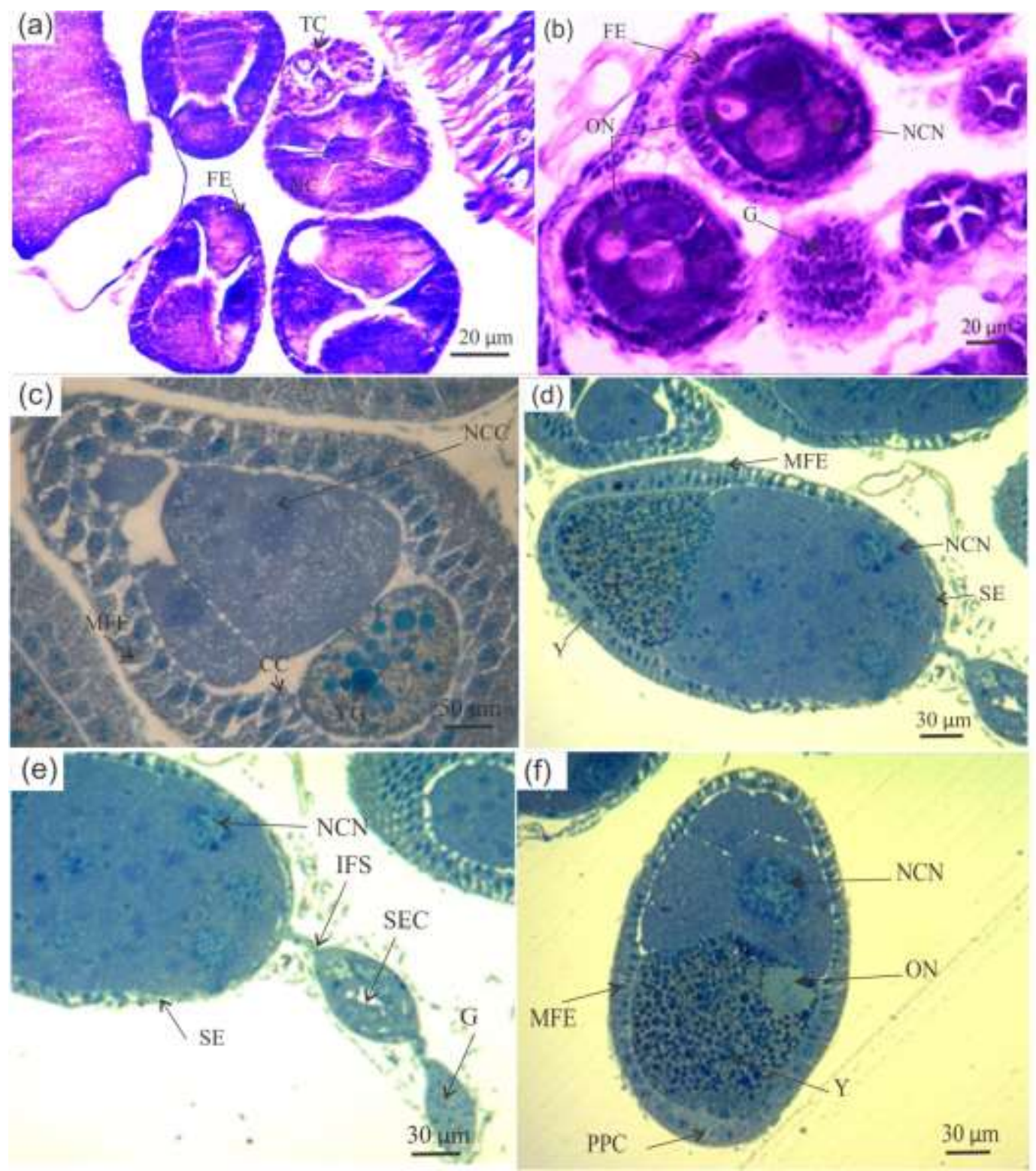

Fig.2 a-b) Photomicrograph of cross section of, a) The second stage of oogenesis showing, nurse cells and terminal cells at the anterior pole of developing oocyte; b) Third stage of oogenesis showing oocyte nucleus in the posterior pole; c-) Semi-thin section early fourth stage of oogenesis showing deposition of yolk granules in the egg chamber and the nurse cells chamber occupies most of oocyte and centripetal cells develop between the oocyte and nurse cells; d \& e) Semi-thin section of fourth stage of oogenesis showing inter follicular stalk between the oocyte and the second egg chamber. The follicular epithelium around the oocyte is columnar (main body follicular cells), around the nurse chamber is squamous (stretched cells); f) Semi-thin section in fifth stage of oogenesis showing yolk granules occupied one half of oocyte, the oocyte nucleus is smaller than the nurse cell nucleus and faintly stained. (CC) centripetal cell; (FE) follicular epithelium; (G) germarium; (IFS) inter follicular stalk; (MFE) main body follicular cells; (NC) nurse cell; (NCC) nurse cell chamber; (NCN) nurse cell nucleus; (ON) oocyte nucleus; (PPC) posterior polar cell; (SE) stretched epithelium; (SEC) second egg chamber; (TC) terminal cells; (Y) yolk; (YG) yolk granule. 
(a)
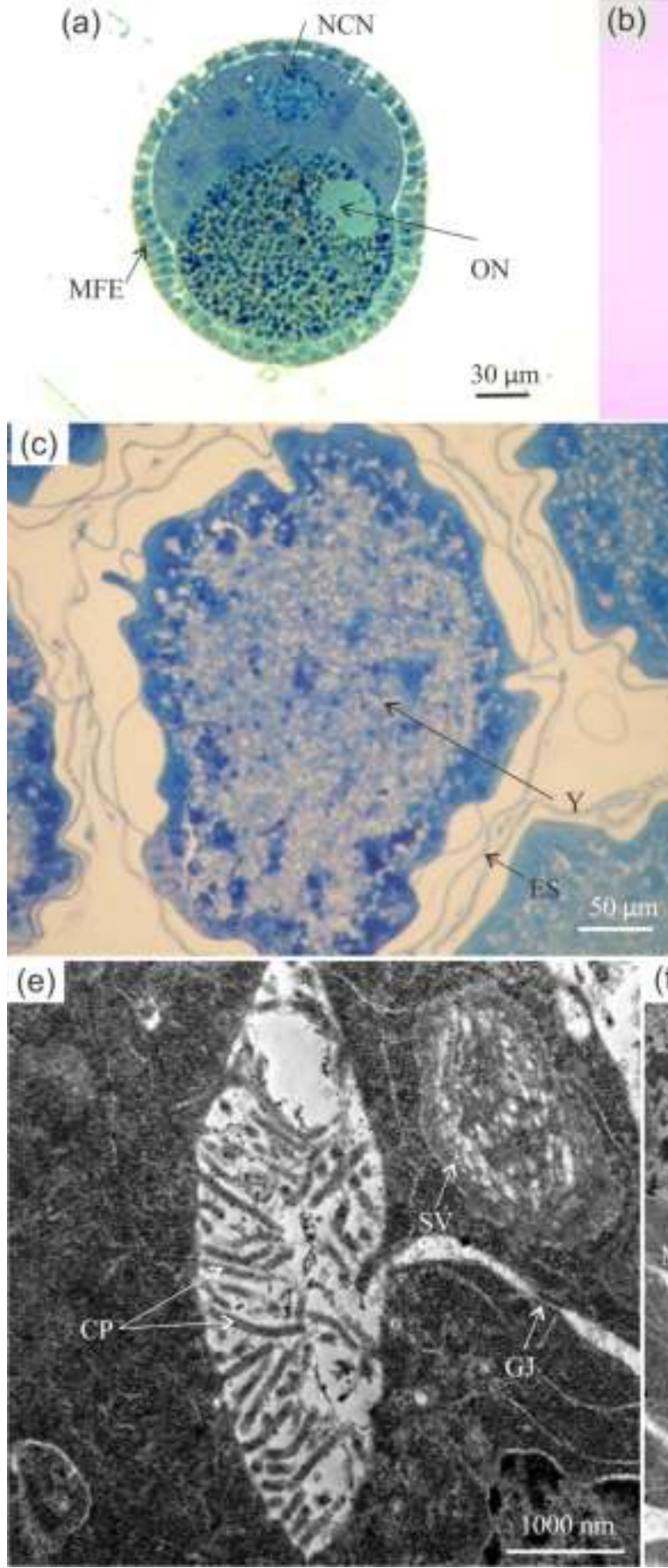

(b)
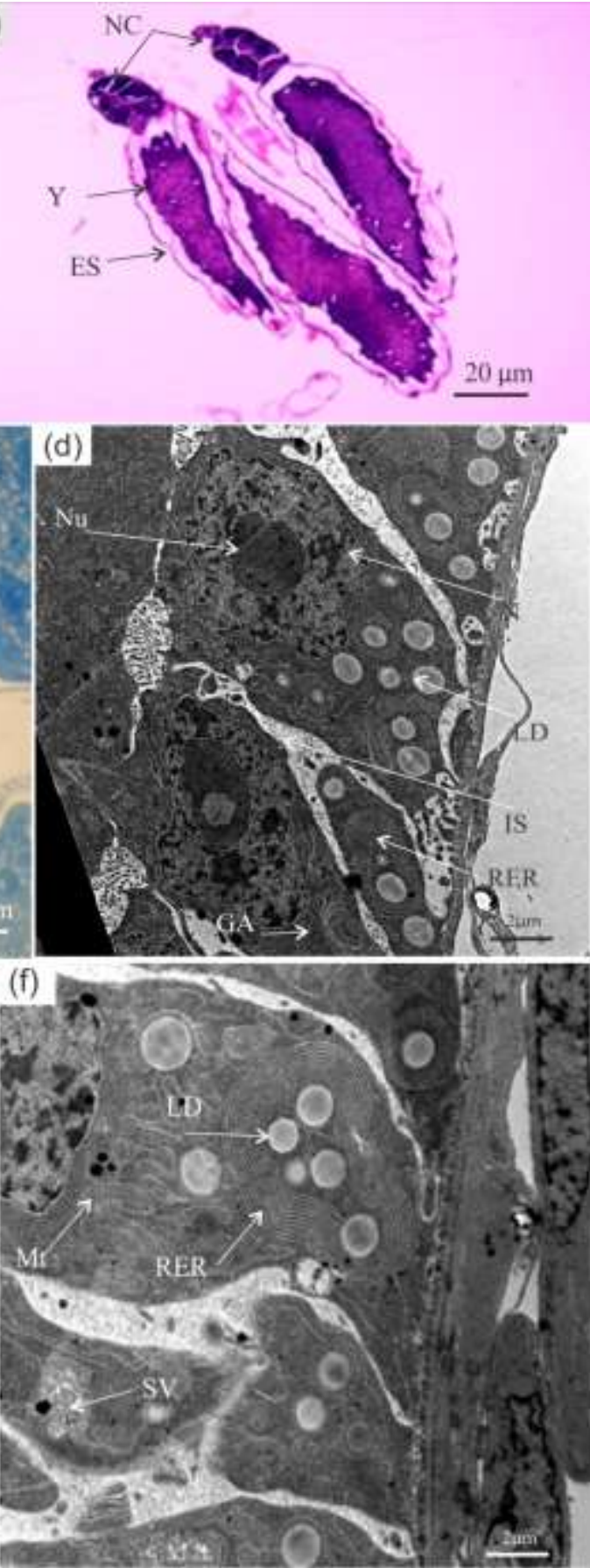

Fig.3 a) Semi-thin section of sixth stage of oogenesis showing oocyte nucleus and yolk occupied two thirds of the oocyte; b) Photomicrograph of longitudinal section of seventh stage of oogenesis showing nurse cells in the apical pole of the oocyte; c) Semi-thin section of last stage of oogenesis showing complete degeneration of nurse cells and the oocyte completely fill the follicle; d-f) TEM microphotograph of cubical follicular epithelium in third stage of oogenesis showing; d) nucleus has prominent nucleolus and dense chromatin, onion or lamellar shaped endoplasmic reticulum, Golgi apparatus and interstitial space between follicular cells; e) Cytoplasmic processes in the space between cubical follicular cell and developing oocyte and gap junction between two adjacent follicular cells; f) Onion or lamellar shaped endoplasmic reticulum which is characteristic feature of follicular epithelium. (Ch) chromatin; (CP) cytoplasmic processes; (ES) eggshell; (GA) Golgi apparatus; (GJ) gap junction; (IS) intercellular space; (MFE) main body follicular epithelium; (Mt) mitochondria; $(\mathrm{LD})$ lipid droplet; $(\mathrm{N})$ nucleus, $(\mathrm{Nu})$ nucleolus; (RER) rough endoplasmic reticulum; (SV) special rosette shaped vesicle; (Y) yolk. 


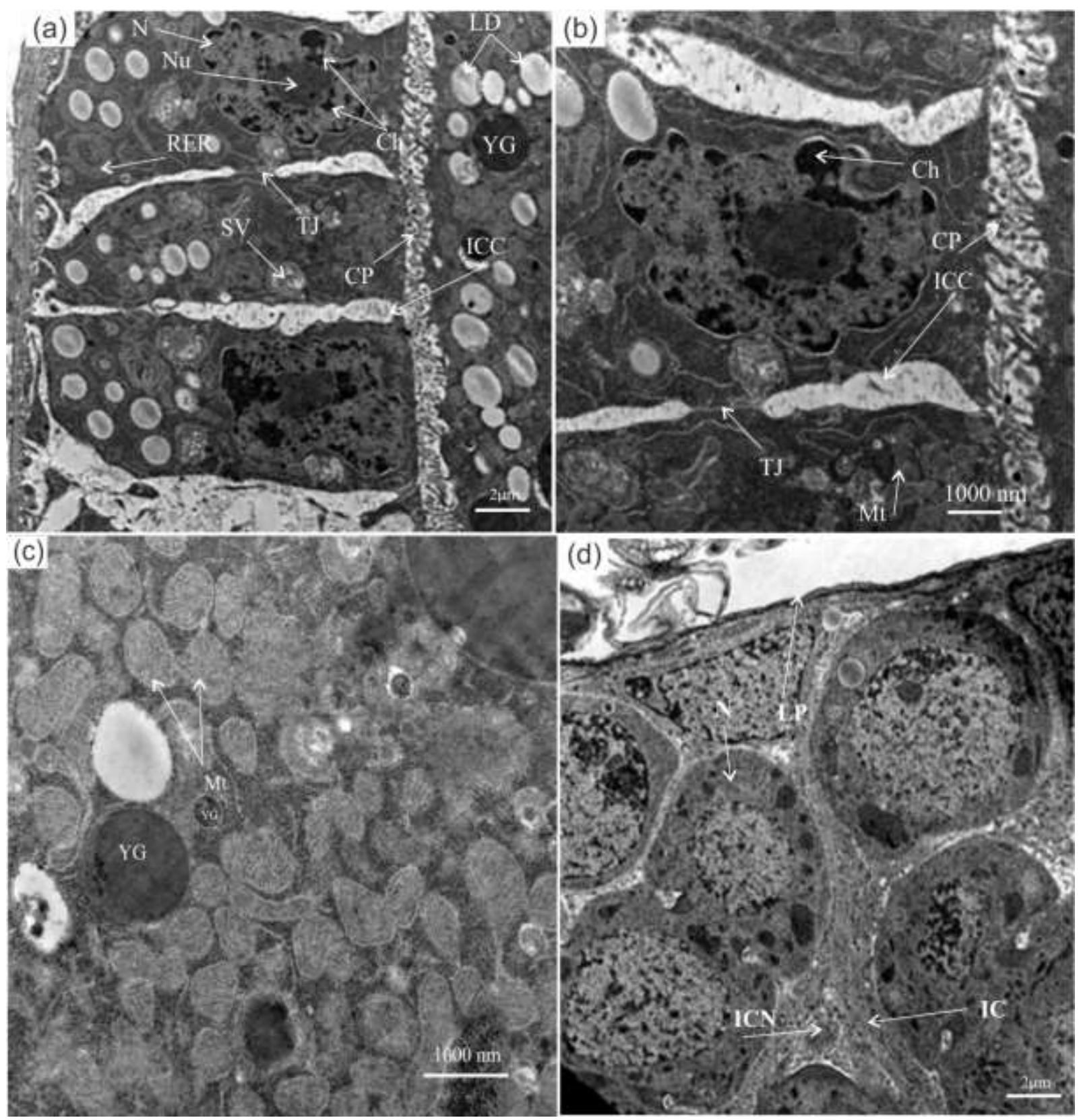

Fig.4 a-d) TEM microphotograph in fourth stage oogenesis showing, a) Main body follicular cells have nucleus, rough endoplasmic reticulum, specialized rosette shaped vesicles and cytoplasmic processes in interstitial space between cells and yolk mass; b) Higher magnification of a), showing tight junction between two adjacent columnar follicular cells; c) Numerous different shaped mitochondria and different size yolk granules; d) Second egg chamber has cells germinal cells in mitotic division state enclosed by lamina proparia, and interstitial cells are clear. (CP) cytoplasmic processes; (IC) interstitial cell; (ICN) interstitial cell nucleus; (ICC) intercellular cleft; (LD) lipid droplet; (LP) lamina properia; (Mt) mitochondria; (N) nucleus; (RER) rough endoplasmic reticulum; (SV) special rosette shaped vesicle; (TJ) tight junction. 

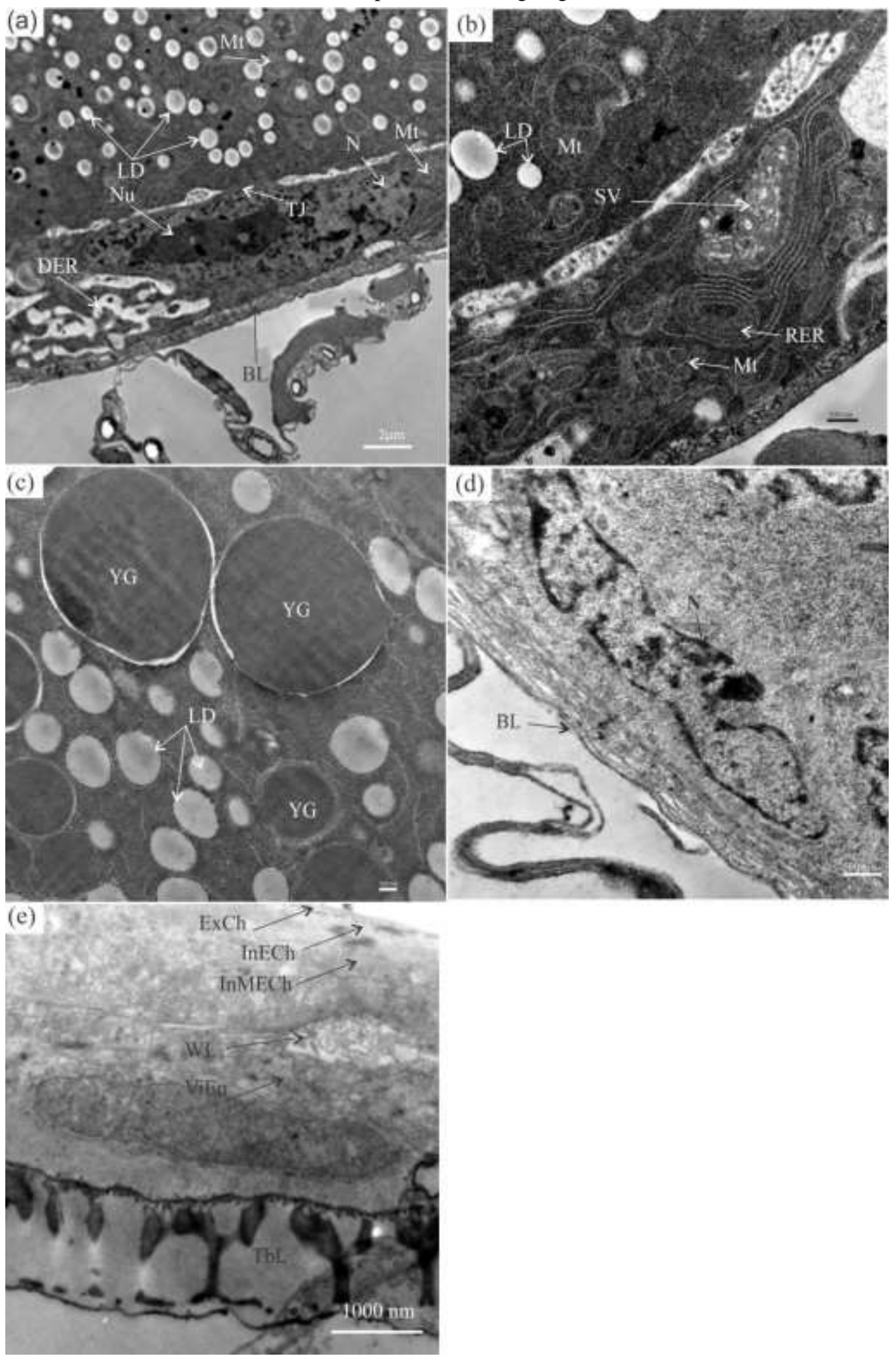

Fig.5 a-c) TEM microphotograph in fourth stage oogenesis showing, a\& b) Squamous follicular epithelium (stretched cells) surrounding the nurse cells, nucleus with clusters of chromatin and prominent nucleolus, mitochondria and rough endoplasmic reticulum; c) Different sizes yolk granules in ooplasm; d) TEM microphotograph of follicular epithelium in seven stage oogenesis showing apoptosis in nurse cells, blebbing in nuclear envelop; e) TEM microphotograph of eggshell showing chorion, wax layer and vitelline envelope with trabecular layer. (BL) basal lamina; (DER) dilated endoplasmic reticulum; (ExCh) exochorion; (InECh) inner endochorion;( InMECh) innermost endochorion; (LD) lipid droplet; (Mt) mitochondria; (N) nucleus; $(\mathrm{Nu})$ nucleolus; (TbL) trabecular layer; (VIEn) vitelline envelop; (WL) wax layer; (TJ) tight junction; (YG) yolk granule. 


\section{DISCUSSION}

The ovary of $L$. silvarium has polytrophic ovarioles which differentiate to form mature oocyte. In polytrophic ovarioles, each ovariole composed of the number of developing follicles. Each follicle has a group of nurse cells which are located in a nurse chamber and connected to the oocytes (Büning, 1979; 2006). The principal role of nurse cells is production and transport of promaterials to the oocyte (Büning, 1994; Matova and Cooley, 2001). The observations in this research is in accordance with many authors on the ultrastructure and development of insect ovaries on dipteran insects, Jaglarz et al. (2008; 2010); Wu et al. (2008); Ahmed and Amin (2018) and other scientists studied the oogenesis of Calliphoridae (Avancini and Prado, 1986; Chaiwong et al., 2012).

The histological changes noticed during oogenesis of $L$. silvarium illustrate that $L$. silvarium female has completed eggs development in eight stage, these results are similar to the results of Clift (1971) in L. cuprina and Chaiwong et al. (2012) in $C$. megacephala who recorded eight stages of ovarian development. In $C$. bezziana female ovaries exhibit ten stages of development (Bedo, 1992) and in Musca domestica six stages were observed (Ahmed and Amin, 2018). In L. silvarium, stage 1 illustrate adult life from zero-day to the second day, while in $C$. hominivorax and $C$. bezziana, these stages occurs only in the pupal stage. The stage $\mathrm{V}$ in $L$. silvarium showed that the developing oocyte occupies one third of the entire follicle, this characteristic to the same stage in $C$. hominivorax (Adams and Reinecke, 1979), while it is characteristic to stage VI in $C$. magacephala (Chaiwong et al., 2012) and $C$. bezziana (Spradbery and Sands,
1976). The stage VIII in L. silvarium associated with the presence of mature egg as in C. magacephala (Chaiwong et al., 2012), and stage IX in $C$. hominivorax (Adams and Reinecke, 1979).

The egg completes its development after three phases, pre-vitellogenesis, vitellogenesis and post- vitellogenesis. The pre-vitellogenesis extend from stage II to stage III. The vitellogenesis extends from stage IV to stage VII and post- vitellogenesis achieved at the end of stage VIII. This observation differs from the finding of Kasper et al. (2015) in L. caesar, who recorded the presence of vitellogenesis phase from IV to stage IX and post vitellogenesis phase exists in stage $X$. Ahmed and Amin (2018) recorded that pervitellogenesis comprise both stage II and III, vitellogenesis include stages IV and V and post- vitellogenesis elucidated by stage VI in $M$. domestica.

Epithelial cells that surrounding the ovarian follicle play a major role in oogenesis process, in the following of yolk promaterials from the haemolymph into the developing oocyte and in the production of vitelline membrane and chorion (Telfer, 1975 and Büning, 1994). This is clear in the current investigation through the presence of high tendency of cytoplasmic processes at the intercellular cleft between the follicular epithelium and junctions between the follicular epithelium and between the follicular epithelium and yolk. The presence of the gap junction between two follicular cells in previtellogenesis allows various molecules and ions to pass directly through a regulated gate between cells. The clear tight junctions observed between two follicular cells and between stretched follicular epithelium enclosing the nurse cells 
and the oocyte in the fourth stage of oogenesis. These junctions seal the plasma membrane of the adjacent cells and prevent leakage of ions transported between epithelial cells.

These findings are in accordance with the results of Oliveria et al. (1986) who declared that the interfollicular channels are one of the most important vitellogenic events in the follicular cells during vitellogenesis. The epithelial cells enveloping follicles change from cubical shape to columnar shape to very thin squamous. These observations were consistent with those of Adham et al. (2009) for Culex pipiens quinquefasciaatus. Samarawickrema (1962) indicated that, in Mansonia spp the epithelial cells enclosing the young follicle have cuboidal shape whenever the follicle grew the epithelial cells diminish in thickness. At the last stages of oogenesis, the follicular cells were very thin and hard to be noticed.

During previtellogensis the cubical follicular epithelium and nurse cells divided mitotically. The follicular cell diversified into polar cells at the opposite side of the developing oocyte (Besse and Pret, 2003). During vitellogenesis stages, the anterior polar cells diversified to terminal cells and the posterior polar cells to the main body follicular cells. The terminal cell diversified to two types, stretched cells and centripetal cells (Jaglarz et al., 2008; 2010). The stretched cells become squamous and enclose the nurse cells. The centripetal cells migrate to the anterior margin of oocyte and separate between the nurse cells and the oocyte. The main-body follicular cells become columnar and cover the lateral sides of the developing oocyte (Jaglarz et al., 2010). As the oogenesis progress and after complete deposition of yolk, the nurse cells transfer their cytoplasm to the oocyte and the nurse cells become diminish and restricted to the apical pole of the oocyte. During the last stages of egg development, the follicular cells reach their final fate and form complex eggshell (Wu et al., 2008; Margaritis et al., 1980). The nurse cells cytoplasm is transferred to the developing oocyte in a process called terminal injection which associated with nurse cells apoptosis (Matova et al., 1999). The eggshell composed of the outermost follicular cell layer, chorion, a wax layer, vitelline envelop and the trabecular layer arranged respectively. The chorion usually subdivided into three sublayers of exochorion, endochorion and innermost endochorion, this resemble the finding of (Chaiwong et $a l ., 2012$ ) and differ from division into to two sublayers of exochorion, endochorion (Margaritis et al., 1980 )

\section{REFERENCES}

Adams, T.S., Reinecke, J.P., 1979. The reproductive physiology of the screw worm Cochiliomyia homininvorax (Diptera: Calliphoridae). I. Oogenesis. J. Med. Entomol., 15 (5-6): 47283.

Adham, F.K., Mehlhorn, H., ELBasheir, Z.M., Yamany, A.S., 2009. Light and electron microscopian studies on the development of the ovaries of Culex pipiens quinquefasciatus(Say), (Diptera: Culicidae). Parasitol. Res., 105: 939-948.

Ahmed, K.M., Amin, H.M., 2018. Ovarian Development of House Fly (Musca domestica L.) (Diptera: Muscidae). Kurdistan J. Applied Res., 3: 45- 51.

Anan'ina, T.V., Vedernikov, A.E., Khodzhanov, A.E., Stegnii, V.N., 2010. Development of ovarioles and nurse cell cytoskeleton in Calliphora erythrocephala Mg (Diptera: 
Calliphoridae). Cell Tissue Biol., 4: 192-198.

Avancini, R. M. P., Prado, A. P., 1986.

Oogenesis in Chrysomya putoria

(Wiedemann)

(Diptera:

Calliphoridae). Int. J. Insect.

Morphol. Embriol., 15: 375- 384.

Bansal, A., Murad, H., 1987. Morphology of the female reproductive organs of the oriental latrine fly, Chrysomyia megacephala F. Japanese J. Sanitary Zool., 38: 233-238.

Beattie, G.A.C., Cheney, J., 1979. Oogenesis in Lucilia cuprina (Wied.) (Diptera:Calliphoridae), 1. Development of nurse cell nuclei, the oocyte nucleus and the follicle cells (sheep blowfly). Aust. J. Zool., 27: 331-348.

Bedo, D.G., 1992. Polytene chromosomes of the old world screw- worm fly (Chrysomya bezziana) and its evolutionary relationships with Lucilia cuprina and Cochiliomyia hominivorax (Diptera:

Calliphoridae). Genome, 35: 294-303.

Besse, F., Pret, A.M., 2003. Apoptosis-mediated cell death within the ovarian polar cell lineage of Drosophila melanogaster. Dev., 130:10171027.

Bolek, M.G., Janovy, J., 2004. Observations on myiasis by the calliphorids, Bufolucilia silvarum and Bufolucilia elongata, in wood frogs. Rana sylvatica, from Southeastern Wisconsin. J. Parasitol., 90(5): 1169- 1171.

Brothers, D.R., 1970. Notes on the saprophagous activity of Bufolucilia silvarum (Meigen)(Diptera:

Calliphoridae). Pan-Pac.

Entomol., 36: 198-200.

Büning, J., 1979. The Telotrophie Nature of Ovarioles of
Polyphage Coleoptera. Zoomorphologie, 93: 51-57.

Büning, J., 1994. The Insect Ovary: Ultrastructure, Previtellogenic Growth and Phylogeny, New York: Chapman Hall.

Büning, J., 2006. Ovariole Structure Supports Sister-Group Relationship of Neuropterida and Coleoptera. Arthropod Syst. Physiol., 64 (2): 115-126.

Chaiwong, T.,Sukontason, K., Chaisri, U.,Kuntalue, B., Vogtsberger, R.C., Sukontason, K.L, 2012. Ovarian ultrastructure and development of the blow fly, Chrysomya megacephala (Diptera: Calliphoridae). Inter. J. Parasit. Res., 4 (1): 65-70.

Clift, A.D., 1971.Control of germarial activity and yolk deposition in nonterminal oocytes of Lucilia cuprina. J. Insect Physiol., 17(4): 601- 606.

David, J.A.O., Rocha, T., Caetano, F.H., 2008. Ultramorphological characteristics of Chrysomya megacephala (Diptera, Calliphoridae) eggs and its eclosion. Micron, 39 (8): 11341137.

Dodge, H.R., 1952. A possible case of blowfly myiasis in a rat, with notes on the bionomics of Bufolucilia silvarum. Entomol. News, 63: 212-214.

Eaton, B.R., Moenting, A.E., Paszkowski, C.A., Shpeley, D., 2008. Myiasis by Lucilia silvarum (Calliphoridae) in amphibian species in boreal Alberta. Canada J. Parasit., 94 (4): 949-952.

El-Khateeb, R.M., Abdel-Shafy, S., Zayed, A.A., 2003. Insecticidal effects of neem seed and vegetable oils on larval and pupal stages of sheep blowfly, Lucilia sericata (Diptera: 
Calliphoridae). J. Egypt. Vet. Med. Assoc., 63: 255- 268.

Ghandour, A.M., 1988. Health hazards in humans and animals caused by imported livestock diseases in Saudi Arabia. In: Buttiker, W. \& Krupp F. (Eds.), Fauna of Saudi Arabia. NCWCD Riyadh and Pro Entomologia, Basle, Switzerland. Vol. 9, pp. 468-477.

Groth, U., Reissmüller, H., 1973. Beziehungen synanthroper Fliegen $\quad \mathrm{zu}$, I. Kleintierleichen,Teil: Methodik, Vor- und Hauptversuche, Angew. Parasitol., 14: 83-100.

Jaglarz, M.K., Krzeminski, W., Bilinski, S.M., 2008. Structure of the ovaries and follicular epithelium morphogenesis in Drosophila and its kin. Dev. Genes Evol., 218: 399- 411.

Jaglarz, M.K., Kubrakiewicz, J., Bilinski, S.M., 2010. A novel pattern of follicular epithelium morphogenesis in higher dipterans. Zool., 113: 91-99.

Kasper, J., Hartley, S., Schatkowski, S., Hoch, H., 2015. The Influence of the Physiological Stage of Lucilia caesar (L.) (Diptera: Calliphoridae) Females on the Attraction of Carrion Odor. Insect Behav., 28:183-201. Margaritis, L., Kafatos, F., Petri, W., 1980. The eggshell of Drosophila melanogaster: I. Fine structure of the layers and regions of the wild-type eggshell. J. Cell Sci., 43:1-35.

Matova, N., Cooley, L., 2001. Comparative aspects of animal oogenesis. Dev. Biol., 231: 291320.
Matova, N., Mahajan-Miklos, S., Mooseker, M.S., Cooley, L., 1999. Drosophila Quail, a villinrelated protein, bundles actin filaments in apoptotic nurse cells. Dev., 126: 5645-5657.

Oliveria, P.L., Katia, C.G., Damiao, M.G., Hatisaburo, M., 1986. Uptake of yolk proteins in Rhodnius prolexus. J. Insect Physiol., 32: 859-866.

Prado e Castro, C., Souse, J.P., Arnaldos, M.I., Gaspar.J., García, M.D., 2011. Blowflies (Diptera: Calliphoridae) activity in sun exposed and shaded carrion in Portugal. Ann. Soc. Entomol. France, 47 (1-2): 128139.

Samarawickrema, W.A., 1962. Changes in the ovarariole of Mansonia (Mansonioides) mosquitoes in relation to age determination, Ann. Trop. Med. Parasitol., 56: 110-126.

Smith, K. G. V., 1986. A Manual of Forensic Entomology. British Museum of Natural History, London. 207 pp.

Spradbery, J.P., Sands, D.P.A., 1976. Reproductive system and terminalia of the Old-world Screw-worm fly Chrysomya bezziana ViII. (Diptera: Calliphoridae). Int. J. Insect Morphol. Embryol., 5: 409-421.

Telfer, W., 1975. Development and physiology of the oocyte nurse cell syncytium. Adv. Insect Physiol., 11: 223-319.

Wu, X., Tanwar, P.S., Raftery, L.A., 2008. Drosophila follicle cells: morphogenesis in an eggshell. Semin. Cell Dev. Biol., 19: 271282. 


\section{ARABIC SUMMERY}

التركيب الفائق الاقة للخلايا الطلائية الجرابية أثناء تكوين البويضات في الليوسيليا سيلفاريوم

(ثنائية الاجنحة: كاليفوريدي) البورين البويف)

كريمة خاطر

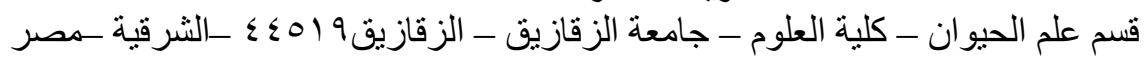

تعتبر الليوسيليا سيلفاريوم من انواع الذباب الازرق ذو الاهمية الطبية الكبيرة .تم تشريح و فحص المبيضين فى الإنى

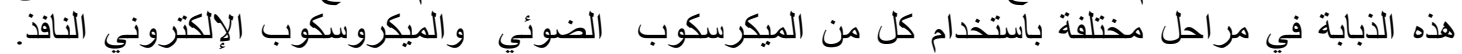

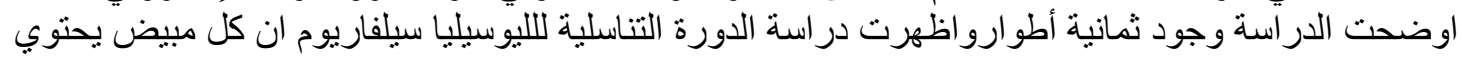

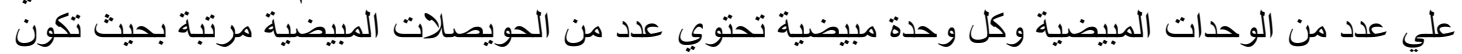

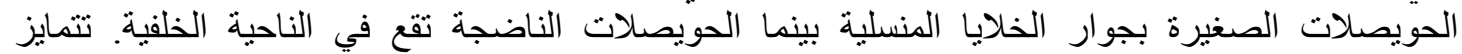

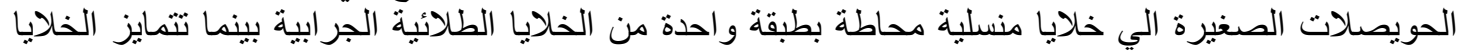

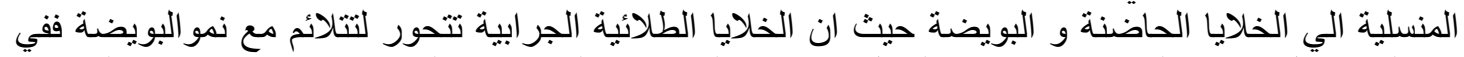

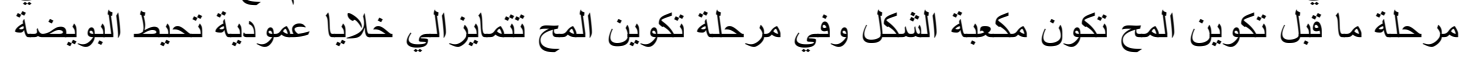

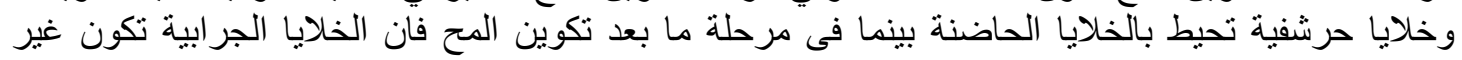
و واضحة لانها شاركت في تكوين غلاف تصلاف البويضة. 